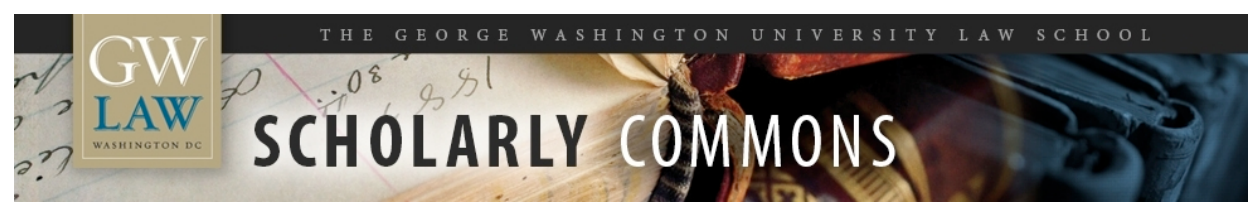

\title{
The U.S.-Mexico-Canada Agreement (USMCA): Some Surprising Outcomes in Procurement
}

Christopher R. Yukins

George Washington University Law School, cyukins@law.gwu.edu

Follow this and additional works at: https://scholarship.law.gwu.edu/faculty_publications

Part of the Law Commons

\section{Recommended Citation}

Yukins, Christopher R., The U.S.-Mexico-Canada Agreement (USMCA): Some Surprising Outcomes in Procurement (2018). GWU Law School Public Law Research Paper No. 2018-45; 60 Gov. Contractor para. 308 (Oct. 10, 2018); GWU Law School Public Law Research Paper No. 2018-45; GWU Legal Studies Research Paper No. 2018-45. Available at SSRN: https://ssrn.com/abstract=3268740

This Article is brought to you for free and open access by the Faculty Scholarship at Scholarly Commons. It has been accepted for inclusion in GW Law Faculty Publications \& Other Works by an authorized administrator of Scholarly Commons. For more information, please contact spagel@law.gwu.edu. 

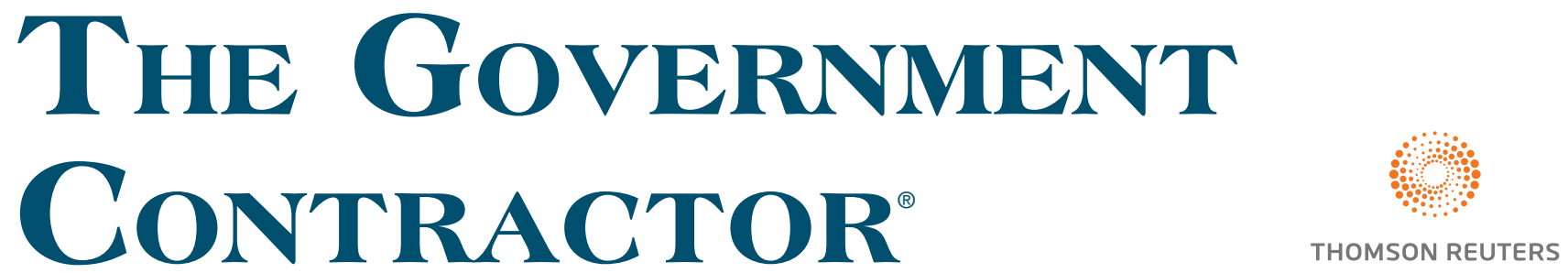

Information and Analysis on Legal Aspects of Procurement

Vol. 60, No. 37

October 10, 2018

\section{Focus}

\section{308}

\section{FEATURE COMMENT: The U.S.-Mexico- Canada Agreement (USMCA): Some Surprising Outcomes In Procurement}

The Trump administration recently released the proposed text of the U.S.-Mexico-Canada Agreement (USMCA), a major regional trade agreement that, if ratified, would replace the North American Free Trade Agreement (NAFTA). While the government procurement chapter of the proposed USMCA was largely a copy-and-paste from the abandoned Trans-Pacific Partnership agreement (TPP), the procurement chapter of the USMCA did contain a few major surprises-including the omission of Canada. This article reviews the background to the USMCA, some of the most important elements of the agreement, and the lessons learned for future international cooperation in procurement policy and law.

Background-The U.S.' commitment to open international trade can be traced back to the time of the republic's founding, when in 1776 Adam Smith published The Wealth of Nations. Smith argued that the mercantilist, protectionist policies which guided Britain were short-sighted, and that nations instead should acknowledge other nations' comparative advantages and open trading channels to foster mutual prosperity. In time, arguments such as Smith's in favor of free trade became a cornerstone of Western economic policy.

That commitment to free trade ebbed badly during the Depression, when economic pressures brought the U.S. and other Western nations to embrace protectionism. The Buy American Act was passed in 1933, and in Europe several nations, including the ascendant Nazi Germany, pressed for protectionism. Many felt that those forces of protectionism and isolationism contributed to the catastrophe of World War II. See, e.g., Palen, "Protectionism 100 Years Ago Helped Ignite a World War. Could It Happen Again?, Wash. Post, June 30, 2017.

As a result, postwar U.S. policy shifted in favor of open trade, as the U.S. took a central role in a new global economic order. Immediately after the war, the U.S. State Department published a proposed charter, www.worldtradelaw.net/misc / Suggested\%20Charter.pdf, for an international organization which eventually became the World Trade Organization (WTO).

Government procurement was always part of these postwar efforts to open trade. See generally Yukins \& Schooner, "Incrementalism: Eroding the Impediments to a Global Public Procurement Market," 38 Geo. J. Int'l L. 529 (2007), papers.ssrn.com / sol3 / papers.cfm?abstract_id=1002446. The proposed charter put forward by the U.S., for example, explicitly urged that government procurement be included in the new free trade arrangements, and government procurement eventually became the subject of a separate plurilateral agreement under the WTO, which is now known as the Agreement on Government Procurement (GPA). www.wto. org/gpa. Members of the WTO-so far, generally only the most highly industrialized memberselect to join the GPA on a plurilateral basis, and so negotiate common and bilateral market arrangements regarding procurement trade. See, e.g., WTO, "Government Procurement Agreement: Opening Markets and Promoting Good Governance" (2015), www.wto.org/english/thewto_e/20y_e/ gpa_brochure2015_e.pdf; Anderson, Schooner \& Swan, “The WTO's Revised Government Procurement Agreement-An Important Milestone Toward Greater Market Access And Transparency In Global Public Procurement Markets," 54 GC II 1; papers. ssrn.com/sol3 / papers.cfm?abstract_id=1984216.

The U.S. has also negotiated a number of regional and bilateral free trade agreements which 
include chapters on procurement, and bilateral free trade agreements regarding defense (known as "reciprocal defense procurement agreements") with its allies. The most important regional free trade agreement for the U.S. was NAFTA, although NAFTA's Chapter 10, the procurement chapter, was largely an unfinished work between the U.S., Canada and Mexico. See Yukins, "International Protection of Free Trade in Procurement Under NAFTA's Chapter 10 on Public Procurement: The Pathway from NAFTA to WTO Government Procurement Agreement to a Potential European-US Transatlantic Trade and Investment Partnership," in Transnational Law of Public Contracts 107 (2016). The half-finished nature of NAFTA's procurement chapter was less important because two of NAFTA's parties, the U.S. and Canada, were also members of the WTO GPA, and in recent years all three parties looked forward to joining the TPP.

Because NAFTA's Chapter 10 left significant gaps, in early 2016 Canada, Mexico and the U.S. tentatively agreed by side letters, ustr.gov/sites / default / files / TPP-Final-Text-Letter-Exchange-US$C A-M X$-re-GP-Procedures.pdf, that they would replace NAFTA Chapter 10 with a new procurement chapter in a much broader regional trade agreement, the TPP, which would have included many nations around the Pacific Rim. The TPP procurement chapter was largely built on the terms of the WTO GPA. See, e.g., Gorski, "The Impact of the TPP on Opening Government Procurement to International Competition in the Asia-Pacific Region," 8(2) Trade L. \& Dev. 66 (2016). The TPP thus would have linked Pacific Rim nations (many of whom, such as Malaysia and Vietnam, are not members of the GPA) to the community of nations that have committed to open their procurement markets under common best practices per the GPA.

All of that changed abruptly, however, when President Trump took office in January 2017. True to his campaign promises, Trump canceled the U.S.' commitment to the proposed TPP (which other Pacific Rim nations continued to pursue, as discussed below), and the Trump administration launched a long, bruising renegotiation of NAFTA with Canada and Mexico.

Taken in sum, the prior chain of events meant that, if procurement were viewed in isolation, there would be a relatively simple measure of success for the U.S. in the renegotiation of NAFTA: would the renegotiated agreement (what became known as the
USMCA) include a procurement chapter that was better than the terms the U.S. would have achieved under TPP?

Assessing the Procurement Chapter in the USMCA-Viewing the procurement provisions of the USMCA in isolation, the answer is probably no: taken alone, the USMCA's procurement chapter probably left the U.S. in a weaker position than the TPP, because of the reduced impact and coverage of the USMCA's procurement chapter. That analysis is artificial, of course, because the procurement chapter is only one of many chapters to the agreement, and the USMCA as a whole promises the U.S. gains in other markets, such as dairy and automobile manufacturing. But the key features of the USMCA's procurement chapter, including its narrower coverage, do offer important lessons for open markets in procurement, whether viewed regionally or globally.

In the NAFTA renegotiations, for political reasons (the imminent shift in government in Mexico City), Mexico reached agreement first with the U.S. The terms of the new USMCA were not publicly released, however, until Canada agreed to join the new agreement as well. See ustr.gov/trade-agreements / free-trade-agreements / united-states-mexico-canadaagreement. The procurement chapter in the proposed USMCA included several important provisions, some of which were quite surprising:

- No Canada: Probably the most startling provision was the complete omission of Canada from the procurement provisions. Article 13.2 of the proposed agreement excludes Canada from the procurement chapter, and Canada has explained, see, e.g., Government of Canada, "Summary Backgrounder: United States - Mexico - Canada Agreement," international.gc.ca/trade-commerce/trade-agreements-accords-commerciaux/ agr-acc / usmca-aeumc / summary-sommaire. aspx?lang=eng, that under the new arrangement, with regard to procurement:

- Canada's relationship with the U.S. will be governed by the GPA, in which both countries are members.

- Canada's relationship with Mexico will be governed by the Comprehensive and Progressive Agreement on Trans-Pacific Partnership (CPTPP), the successor to the TPP, which awaits ratification by the member nations, international.gc.ca/ trade-commerce / trade-agreements-accords- 
commerciaux/agr-acc/cptpp-ptpgp/index. asp $x$ ?lang $=$ eng.

- "Strict Reciprocity" Abandoned: During the course of the NAFTA renegotiation, a series of public reports indicated that the U.S. might press for what some have termed "strict" reciprocity: limiting Canadian and Mexican vendors' access to the U.S. federal market, on a dollar-for-dollar basis, to that afforded in the vendors' home markets. See, e.g., Rodriguez \& Palmer, "Freeland Returns to Canada Empty-Handed," POLITICO, Sept. 21, 2018, www.politico.com/newsletters / morning-trade/2018/09/21/freeland-returnsto-canada-empty-handed-347615. (Under this approach, for example, if Nation X has only $\$ 1$ billion in accessible public procurement, Nation X's vendors will have access to only $\$ 1$ billion of the $\$ 500$ billion U.S. federal market.) This type of strict reciprocity was bitterly opposed in public statements by Canadian negotiators, see, e.g., Jasso, “Canada's Lead NAFTA Negotiator Criticizes U.S. Proposal as Freeland Heads to Washington," Globe \& Mail, Feb. 13, 2018, and was roundly criticized by U.S. industry, which feared that Mexican vendors would be willing to forfeit their tenuous access to the U.S. federal market in exchange for new, draconian limits on U.S. access to the Mexican public markets, see, e.g., Murphy, U.S. Chamber of Commerce, "Gutting NAFTA's Procurement Rules Could Cost Americans Billions" (Jan. 24, 2018), uschamber.com/series / modernizing-nafta / gutting-nafta-s-procurement-rules-couldcost-americans-billions. The final proposed text of the USMCA did not reflect strict reciprocity in procurement, but instead followed a more traditional (and liberal) approach to reciprocal market access.

- Text Followed Prior International Agreements: Although the USMCA negotiations followed on a very public repudiation of the TPP negotiations by President Trump, as several observers have pointed out, the broader USMCA drew largely from the draft TPP agreement. See, e.g., Collins, "New Trade Deal with Canada, Mexico Borrows Heavily from Pact that Trump Abandoned," USA Today, Oct. 3, 2018. That was certainly true with regard to procurement. A close examination of the legal texts of the
USMCA's chapter 13 and the TPP's chapter 15 (the government procurement chapters) confirms the striking similarities between the draft USMCA and the draft TPP agreement, and as noted the draft TPP provisions were in turn drawn from the WTO GPA.

- Coverage Not Expanded: As Jean Heilman Grier explained in an excellent review of the new agreement, "USMCA - Modernized NAFTA: Procurement" (Oct. 5, 2018), trade. djaghe.com / ? $p=5174$, the new U.S. bilateral arrangement with Mexico largely mirrored longstanding NAFTA coverage, and the access allowed U.S. vendors to Canadian public markets under the GPA may, in some cases, be more limited than under Canada's existing NAFTA agreement with the U.S.

What was not surprising, however, was that the new agreement did not give Mexico (or Canada) broader access to U.S. subcentral (state and local) procurement markets, which has been a recurring demand from both Canadian and European negotiators. (The recent Comprehensive Economic and Trade Agreement (CETA) between Canada and the European Union markedly improved Europeans' access to Canadian local and provincial public markets, much as the Europeans afford access to their subcentral markets as a matter of course.)

Conclusion-Despite promises by President Trump that the new USMCA would be an important improvement upon NAFTA, and despite obvious gaps in the prior NAFTA regime regarding procurement, see, e.g., Yukins \& Green, "International Trade Agreements and U. S. Procurement Law" (chapter in forthcoming volume, American Bar Association, 2018), the USMCA - the Trump administration's leading achievement in trade-reflects little real change in the trading regime regarding procurement.

The outcome of the USMCA negotiations nevertheless may offer lessons for future trade arrangements regarding procurement. First, if what was perhaps the most contentious trade negotiations in modern times yielded almost no changes regarding procurement, future trade agreements may follow the same gentle, upward trajectory in their approach to procurement. Trade agreements regarding procurement may, in other words, be relatively stable and predictable.

Second, Canada's surprising decision to abandon the procurement chapter in the USMCA, in favor of the GPA's protections, highlighted another possible 
negotiating strategy for nations locked in broader bilateral negotiations with the U.S.: to sever procurement from those negotiations, and instead to seek access to public procurement markets through the GPA. A number of nations in the former Soviet bloc are seeking to join the GPA, supported by the European Bank for Reconstruction and Development, and other nations in or near the accession process-including China and Russia-may decide that it is simpler to address procurement through the GPA, rather than through bilateral negotiations with the U.S.

Finally, the provisional end of the USMCA negotiations shifts attention to other pending procurement issues. If the existing universe of procurement agreements remains relatively intact-if the U.S. does not withdraw from the GPA, for example-focus may shift again to the Trump administration's "Buy American" initiative, under which the U.S. may impose more extreme domestic preferences on contracts valued below the various trade agreements' monetary thresholds. See, e.g., Yukins, "The Trump Administration's Policy Options in International Procurement," 2016 West Gov. Contracts Year in Rev. Sess. 2-I (Feb. 2017), papers.ssrn.com / sol3 / papers.cfm?abstract_id $=2925953$.

At the same time, the relative stability of the trade agreements suggests that it may be easier to achieve regulatory cooperation among nations to reduce barriers to trade, as the European Union and the U.S. now seek to do in certain industrial sectors, see, e.g., Cong. Res. Serv., "U.S.-EU Trade and Economic Issues" (Aug. 1, 2018), fas.org / sgp / crs/row/IF10931.pdf, and as the U.S. Access Board did in procurement when it adopted truly "global" information technology accessibility standards under Section 508 of the Rehabilitation Act, in cooperation with the European Commission, see, e.g., U.S. Architectural and Transportation Compliance Board, "Board and European Commission Cooperation Recognized at International Forum," 22 Access Currents 1 (2016) (available on Westlaw). Because tensions may rise in other areas, such as a new protectionism in European defense markets, see, e.g., Yukins, "European Commission Proposes Expanding The European Defence Fund-A Major Potential Barrier To Transatlantic Defense Procurement," 60 GC II 196, the relative stability in procurement agreements that the USMCA seemed to confirm is a welcome sign for the international procurement community.

This Feature Comment was written for THE Government Contractor by Christopher Yukins, the Lynn David Research Professor in Government Procurement Law at the George Washington University Law School, Washington D.C. This article draws in part upon a paper that Professor Yukins will present at an interdisciplinary conference in procurement at the Sorbonne University, Paris in October 2018. 